\title{
PROTEINS IN THE COLLOIDAL GOLD REACTION
}

\author{
By JOSEPH BERNSOHN AND EARLE K. BORMAN \\ (From the Bureau of Laboratories, Connecticut State Department of Health, \\ Hartford, Connecticut)
}

(Received for publication April 5, 1947)

The colloidal gold test developed almost 35 years ago by Lange (1) has been utilized in studies of cerebrospinal pathology and of liver dysfunction with little more than a general understanding of the basic reasons for the production of the several reaction patterns. Rationalization of the mode of reaction by experimenting with blood protein fractions obtained by the usual salting out methods is difficult, if not impossible, because the fractions so obtained are mixtures (2) of proteins defined arbitrarily.

A promising line of attack upon the problem has been opened up by newer methods for the separation of the blood proteins $(3,4,5)$, particularly those separable as electrophoretically homogeneous fractions. It has already been established $(6,7)$ that the gamma globulin fraction is responsible for the coagulation of the gold sol. The protective action postulated for the serum albumin, however, never has been demonstrated conclusively with concentrations likely to be encountered in body fluids. In investigating the use of the colloidal gold reaction for the detection of liver damage, the authors have used blood protein fractions prepared by the newer methods in an attempt to determine the relationships between relative concentrations of the protein fractions and the reaction curves obtained.

\section{MATERIALS}

The blood protein fractions ${ }^{1}$ used in this study were described as follows:

1 The products of plasma fractionation employed in this work were developed from blood, collected by the American Red Cross, by the Department of Physical Chemistry, Harvard Medical School, Boston, Massachusetts, under a contract, recommended by the Committee on Medical Research, between the Office of Scientific Research and Development and Harvard University. The authors wish to express their gratitude to Dr. John T. Edsall of Harvard University who furnished these materials.

\begin{tabular}{|c|c|c|c|c|c|c|c|c|}
\hline \multirow{2}{*}{ Fraction } & \multirow{2}{*}{$\begin{array}{l}\text { Plasma } \\
\text { prepara- } \\
\text { tion no. }\end{array}$} & \multicolumn{7}{|c|}{$\begin{array}{l}\text { Distribution of electrophoretic } \\
\text { components }\end{array}$} \\
\hline & & $\boldsymbol{\gamma}$ & F & $\beta_{2}$ & $\beta_{1}$ & $\alpha_{2}$ & $\alpha_{1}$ & Alb. \\
\hline $\begin{array}{l}\text { II-1,2 } \\
\text { V } \\
\text { III-0 total* } \\
\text { IV-1* } \\
\text { IV-3,4† }\end{array}$ & $\begin{array}{l}184 \\
185 \\
175 \\
185 \\
184\end{array}$ & 96 & 18 & 213 & $\begin{array}{l}64 \\
35\end{array}$ & $\begin{array}{r}1 \\
18 \\
26\end{array}$ & $\begin{array}{r}2 \\
5 \\
40 \\
41 \\
21\end{array}$ & $\begin{array}{l}97 \\
33 \ddagger \\
16\end{array}$ \\
\hline
\end{tabular}

* Rich in lipoprotein.

$\dagger$ Poor in lipoprotein.

$\ddagger$ Figures for albumin and $\alpha_{1}$ are approximate due to difficulty in resolving fraction.

\section{METHODS}

The methods of preparing the gold sol and performing the tests were those recently described by Lange $(8,9,10)$. Thus, the tests were performed with comparable gold sols on dilutions of experimental material in phosphate buffer,

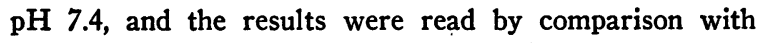
prepared standards of graded color values.

In all cases, the plasma protein fractions were prepared in desired concentrations by dissolving them in the phosphate buffer. In later phases of the investigation, concentrations were based upon protein content as calculated from Kjeldahl determinations $(\mathrm{N} \times 6.25) .^{2}$

In performing the tests, serial dilutions of each solution under test, $0.5 \mathrm{ml}$. per tube, were prepared in such manner that the dilutions increased by one-third with each successive tube. To each of these, $2.5 \mathrm{ml}$. of colloidal gold sol were added and the tubes were shaken and allowed to stand at room temperature for 2 hours. Readings were then made against a graded series of standards varying from 0 (unchanged) to 20 (colorless) after the manner suggested by Lange (8).

\section{RESULTS}

Figure 1 shows graphically the differing effects of equivalent concentrations of the several protein fractions upon the gold sol. These graphs have been plotted for each fraction from results obtained on 20 serial dilutions prepared after the manner described above. The horizontal axes of these

\footnotetext{
2 The use of the conventional nitrogen factor for fractions containing alpha and beta globulins with lipids results in some inaccuracy.
} 


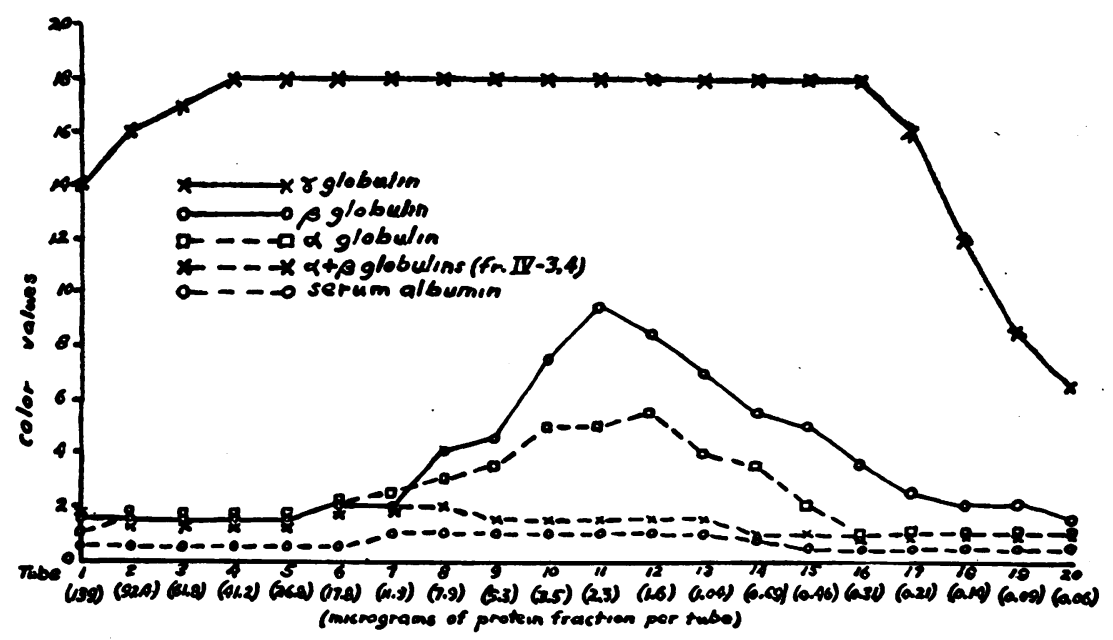

Fig. 1. Effect of Protein Fractions on 2.5 ML. Gold Sol ( $\mathrm{pH} 7.4$ )

- graphs and of those to follow show uniform spacings between successive dilutions; this gives the same effect as a semi-logarithmic scale with the abscissa showing the logarithms of increasing dilutions. It will be noted that neither serum albumin nor fraction IV-3,4 containing a mixture of alpha and beta globulins exerted any significant coagulatory effect upon the gold sol whereas the gamma globulin was the only fraction with unequivocally coagulatory effects. Fractions III- 0 and IV-1, one containing alpha globulin and the other beta globulin, showed such slight reactivity in the range of concentrations between 1 and $5 \mu \mathrm{g}$. per tube that it seems unlikely that this resulted from any specific coagulatory effect exerted by these globulins per se. Such minimal activity is more likely to have resulted from the presence of other substances in these mixtures. Likewise, the possible role of impurities in the gamma globulin fraction acting as protective colloids cannot be ignored entirely in the interpretation of the apparent slight protection of the sol by concentrations of that fraction above $60 \mu \mathrm{g}$. per tube.

Figure 2 shows the apparent effect of serum albumin upon the coagulatory action of the gamma globulin fraction. Critical analysis of the graphs shows that the protective action of this fraction is nil $^{3}$ since the critical point at which the coagula-

${ }^{3}$ Since these experiments were completed Lange has published data obtained with the use of horse serum al-

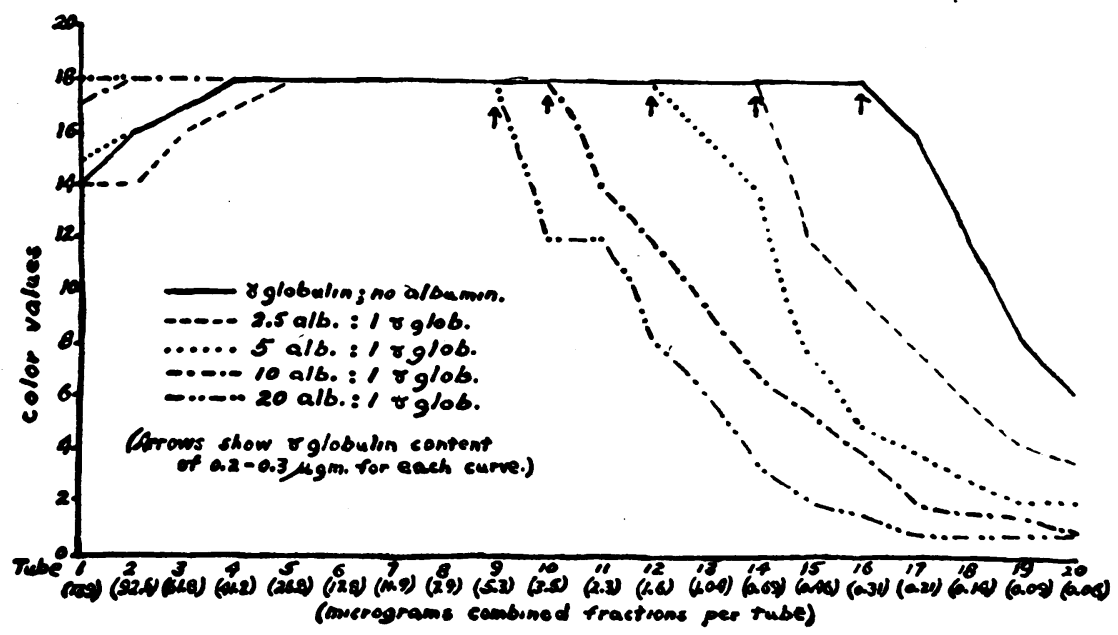

Fig. 2. Effect of Serum Albumin on $\gamma$ Globulin Curve (pH 7.4) 


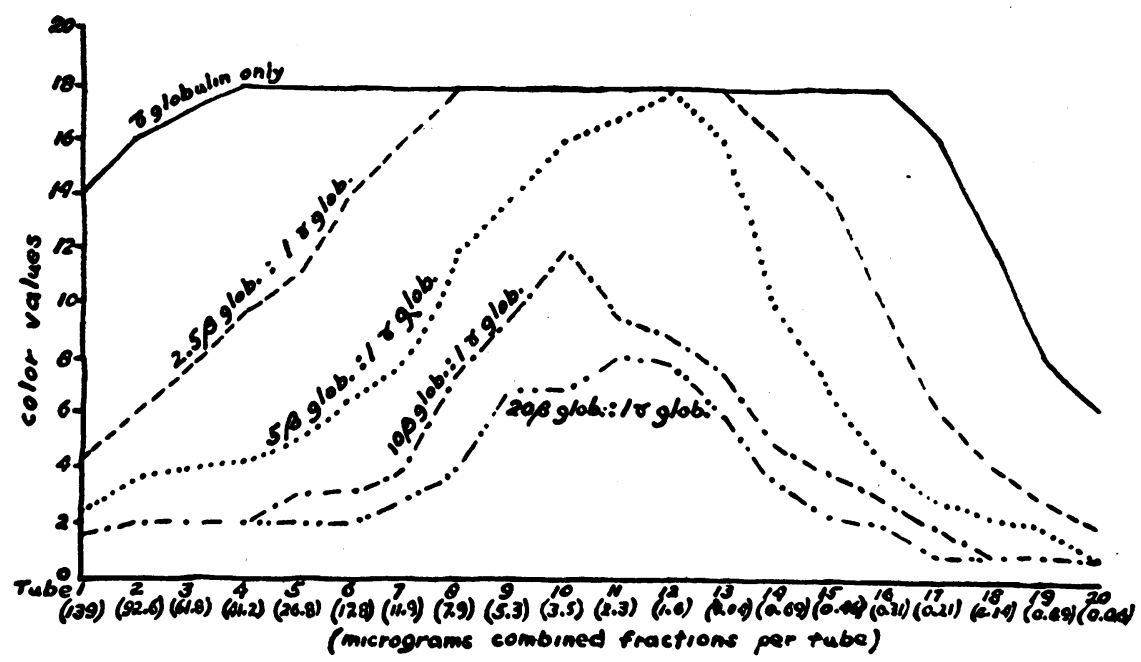

Fig. 3. Effect of $\beta$ Globulin (Fr. III-0) on $\gamma$ Globulin Curve (pH 7.4)

tory reaction diminishes sharply is determined by the actual amount of gamma globulin present in the tube and not upon the albumin to globulin ratio. This critical point is reached when the concentration of gamma globulin drops below $0.3 \mu \mathrm{g}$. per $2.5 \mathrm{ml}$. of gold sol as shown by notations on the chart.

The effect of the lipoprotein fraction III-0 (beta globulin) upon the coagulatory action of the gamma globulin fraction was in marked contrast to that produced by serum albumin. This is shown graphically in Figure 3. Here 2 manifestations of protective action are indicated plainly: (1) Progressive inhibition of coagulatory action of gamma globulin with increasing beta to gamma ratios shown in the graph by longer prozones with ratios of 5:1 and below, and (2) suppression of the ability of gamma globulin to induce complete coagulation of the gold sol as shown by the occurrence of intermediate maximum color values when the ratios rose to $10: 1$ and above. In this series of graphs, the existence of a critical point (or concentration) beyond which the coagulatory action of gamma globulin suddenly diminishes with decreasing concentration is again apparent. Except for the graph illustrating the results with a beta to gamma ratio of $20: 1$, this is

bumin subjected to repeated salting out with $\left(\mathrm{NH}_{4}\right)_{2} \mathrm{SO}_{4}$ which substantiate this observation-cf. C. Lange, Theory of the colloidal gold reaction. I. Reactions between gold sol and isolated protein fractions. J. Lab. and Clin. Med., 1945, 30, 1006. seen to occur at a concentration of $0.3 \mu \mathrm{g}$. gamma globulin per $2.5 \mathrm{ml}$. gold sol. The discrepancy shown in the graph of the 20:1 ratio may be due to technical error since it represents a single determination.

Protective action was also evidenced by fraction IV-1 (alpha globulin) but was somewhat less than that exhibited by beta globulin.

Since fraction IV-3,4 (mixed alpha and beta globulins) contained relatively little lipid as compared with both the fraction labeled alpha globulin and that labeled beta globulin, its protective action

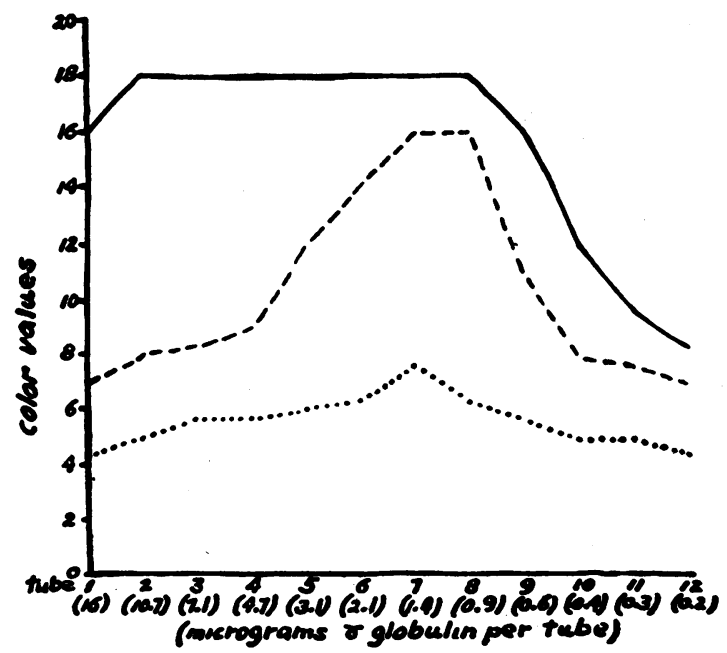

Fig. 4. Protective Action of Fraction IV-3,4 (aß) (pH 7.4)

Relative proportions: $3.0 a \beta: 1 \gamma, \cdots 4.5 \alpha \beta: 1 \gamma$ 
was investigated and results were obtained as shown in Figure 4. The protein concentrations used for this series of tests were adjusted on the basis of $\mathrm{Kjeldahl}$ determinations $(\mathrm{N} \times 6.25)$. The graphs show an effect similar to that produced by the protective action of the beta globulin fraction but somewhat more pronounced. In addition, the smallest concentration of gamma globulin capable of producing maximum coagulation of the sol in the presence of this fraction was about 3 times greater than that noted in previous experiments. These results appear to indicate that the lipid material bound to the proteins in fractions III- 0 and IV-1 played no important role in the protective action of those fractions.

The authors have tried, by combining the fractions in various proportions, to reproduce the curve obtained when diluted normal blood serum (pool of 20 serums) reacts upon a colloidal gold sol. In making these trials it has been assumed that $0.5 \mathrm{ml}$. of a $1: 300$ dilution of normal serum contains about $16 \mu \mathrm{g}$. of gamma globulin. The normal serum curve shows its maximum, nearly colorless reaction at a dilution of $1: 17,000$ (about $0.3 \mu \mathrm{g}$. gamma globulin). The initial dilution of 1:300 shows but a slight reaction indicating a high degree of protection, while less protection occurs as the dilution increases until the maximum coagulation occurs. In serial dilutions above $1: 17,000$ the reaction diminishes rapidly. While similar curves have been obtained with some "artificial serums," these all contained greater quantities of the protective proteins than normal serum. In fact, ratios of protective globulin fractions to gamma globulin as high as $3: 1$ did not show so great protective action as that apparent in normal serum.

\section{DISCUSSION}

The experiments reported have been performed in the presence of a uniform hydrogen ion concentration. The authors have unpublished data indicating that blood proteins other than gamma globulin will act as coagulants in the colloidal gold test at $\mathrm{pH}$ 's on the acid side of their respective isoelectric points and that the coagulant action of gamma globulin is enhanced by lowering the $\mathrm{pH}$. Hence, it is understood that the discussion which follows is predicated upon performance of the test at $\mathrm{pH} 7.4$.
Although it is probable that the gamma globulin fraction used was not composed of a single chemical entity, there seems little doubt, as others have shown, that gamma globulin is the coagulatory protein involved in the colloidal gold reaction of blood serum. The role of serum albumin, however, is not protective; in fact, it is inert toward colloidal gold in a milieu buffered at $\mathrm{pH}$ 7.4. The experiments reported leave little doubt that one or more beta globulins (and probably alpha globulins) are the proteins in blood serum which play the major protective role in this reaction. These considerations pose a number of interesting questions which merit investigation by others with technical and clinical facilities which the authors do not have available.

It seems logical to postulate that abnormal colloidal gold reactions arise from either or both of 2 conditions: (1) Significant change in the gamma globulin content ot the body fluid and (2) alteration in the relative proportions of beta globulin (and possibly alpha globulin) as compared with gamma globulin. Thus, if this theory is true, a spinal fluid giving the typical colloidal gold reaction of general paresis (zone I curve) should contain significantly less of the protective globulins and, in many instances, more gamma globulin than normal spinal fluid. Furthermore, a spinal fluid giving the type of curve associated with the bacterial meningitides (zone III curve) should contain significantly greater quantities of all globulins, particularly of the beta type, than a normal fluid. Reaction patterns associated with certain other conditions, e.g., non-paretic CNS lues (zone II curve), would be explainable on the basis of a moderately altered ratio of the protective globulins to the gamma globulin. Reactions obtained on blood serum in certain types of liver dysfunction are generally of the type which on this basis would be interpreted as arising from a relative decrease in protective globulin content, a hypothesis consistent with the theory that these globulins are elaborated by liver cells while gamma globulin ordinarily is produced elsewhere. The authors are convinced that careful study of the reaction on the basis of these postulates will lead to a more nearly quantitative interpretation of the colloidal gold test.

The utility of the colloidal gold test for the close estimation of gamma globulin content merits fur- 
ther careful investigation. The results reported suggest that there is a critical dilution of gamma globulin beyond which complete coagulation of $2.5 \mathrm{ml}$. of a standardized gold sol does not occur at $\mathrm{pH}$ 7.4. With the sols used, this dilution was found to correspond to a concentration in the neighborhood of $0.3 \mu \mathrm{g}$. of the gamma globulin fraction. Even in the presence of protective colloids within the range of concentrations normally encountered in body fluids, the highest dilution giving the maximum coagulatory action in a series of dilutions appears to depend upon a critical gamma globulin concentration. In the experiments reported, the critical concentration of gamma globulin in the presence of protective colloids is not so sharply defined as in their absence but the authors feel that more nearly exact knowledge of the actual protein content of the experimental material and greater accuracy in measurements than that afforded by the serial dilution technic are needed before this effect can be judged critically. The experiments indicate that relatively pure gamma globulin fractions may be used to advantage in comparing the sensitivities of different gold sols and in standardizing upon a uniform and reproducible type of sol. Conversely, the possibility of using standardized gold sols in testing the purity of protein fractions seems worthy of further study.

The significance of the fact that various combinations of the several protein fractions failed to reproduce the colloidal gold curve yielded by normal human blood serum cannot be ignored. It is not impossible that some fraction other than those investigated comes into play in the reaction of normal serum, but it is also feasible to assume that alterations in the physical state of the proteins involved may occur, even with newer methods of fractionation, and so influence the properties of their artificial admixture as compared with those of serum.

\section{SUM MARY}

Experimental data showing the individual effects of blood fractions on uniformly prepared colloidal gold sols at $\mathrm{pH} 7.4$ are presented which confirm the coagulatory action of gamma globulin and which show that one or more beta globulins (and possibly alpha globulins) are responsible for the protective action of normal body fluids as distinct from the serum albumin which is inert. The use of gamma globulin in determining whether or not 2 batches of gold sol are comparable is suggested. Conversely, a standardized gold sol may be found useful in the analysis of blood fractions. In a discussion of the implications of these results, hypotheses are advanced to account for the usual types of colloidal gold reactions exhibited by body fluids in a milieu buffered at $\mathrm{pH} 7.4$.

\section{BIBLIOGRAPHY}

1. Lange, C., Die Ausflockung kolloidalen Goldes durch Zerebrospinalflüssigkeit bei luetischen Affektionen des Zentralnerven-systems. Ztschr. f. Chemotherap. Leipz., 1912, 1, 47.

2. Tiselius, A., Electrophoresis of serum globulin; electrophoretic analysis of normal and immune sera. Biochem. Jour., 1937, 31, 1464.

3. Cohn, E. J., Oncley, J. L., Strong, L. E., Hughes, W. L., Jr., and Armstrong S. H., Jr., Chemical, clinical, and immunological studies on the products of human plasma production. I. The characterization of the protein fractions of human plasma. J. Clin. Invest., 1944, 23, 417.

4. Williams, J. W., Petermann, M. L., Colovos, G. C., Goodloe, M. B., Oncley, J. L., and Armstrong, S. H., Jr., Chemical, clinical, and immunological studies on the products of human plasma production. II. Electrophoretic and ultracentrifugal studies of human serum albumin and immune serum globulins. J. Clin. Invest., 1944, 23, 433.

5. Cohn, E. J., Strong, L. E., Hughes, W. L., Jr., Mulford, D. J., Ashworth, J. N., Melin, M., Taylor, H. L., Preparation and properties of serum and plasma proteins. IV. A system for the separation into fractions of the protein and lipoprotein components of biological tissues and fluids. J. Am. Chem. Soc., 1946, 68, 459.

6. Gray, S. J., Studies on the mechanism of the spinal fluid colloidal gold reaction. Proc. Soc. Exper. Biol. \& Med., 1942, 51, 401.

7. Kabat, E. A., Moore D. H., and Landow, H., An electrophoretic study of the protein components in cerebrospinal fluid and their relationship to the serum proteins. J. Clin. Invest. 1942, 21, 571.

8. Lange, C., Methods for the examination of spinal fluid. Am. J. Syph., Gonor., \& Ven. Dis., 1939, 23, 638.

9. Lange, C., and Harris, A. H., The significance of the $\mathrm{pH}$ in the gold reaction. J.. Lab. \& Clin. Med., 1944, 29, 970.

10. Lange, C., and Harris, A. H., A citrate gold of optimal and reproducible sensitivity for use in the colloidal gold reaction. Its preparation and control. Am. J. Pub. Health, 1944, 34, 1087. 